\title{
New form of rhizodont voles (Rodentia, Arvicolinae, Clethrionomyini) from Pleistocene of Central Altai (Russia)
}

\author{
Natalia V. Serdyuk \& Alexey S. Tesakov
}

\begin{abstract}
Lower beds of multi-layered Paleolithic site of the Ust'-Kan Cave yielded a heterogeneous material of small mammals containing a characteristic Early Pleistocene association. Along with molars of typical early Biharian forms, few remains of a very hypsodont clethrionomyine vole have been encountered. This form shows weakly differentiated enamel, high dentine tracts, lacks mimomyian characters, and has sparse cement. The combination of characters permits its interpretation as a late rhizodont stage of one of phyletic lineages of modern high mountain voles of the genus Alticola. It shows some similarities with the flat-sculled vole, A. strelzowi. The new form is described as a new genus and species, Altaiomys ustkanicus gen. \& sp. nov.
\end{abstract}

KEY WORDS: Arvicolinae, Alticola, evolution, Early Pleistocene, Altai, Russia.

NataliaV. Serdyuk[nataly@paleo.ru], Paleontological Institute of the Russian Academy of Sciences, Profsoyuznaya 123, Moscow 117997, Russia; Alexey S. Tesakov [tesak@ginras.ru], Geological Institute of the Russian Academy of Sciences, Pyzhevsky per. 7, Moscow 119017, Russia.

\section{Новая форма корнезубых полевок (Rodentia, Arvicolinae, Clethrionomyini) из плейстоцена центрального Алтая (Россия)}

\section{Н.В. Сердюк, А.С. Тесаков}

РЕЗЮМЕ. В нижней части разреза многослойного палеолитического памятника Усть-Канская пещера обнаружены слои с гетерогенным комплексом мелких млекопитающих, включающим характерную ассоциацию раннего плейстоцена (эоплейстоцена). Среди моляров обычных форм раннего бихария отмечены несколько коренных зубов очень гипсодонтной полевки трибы Clethrionomyini со слабо дифференцированной эмалью, высокими трактами, отсутствием мимомисных признаков и малым количеством цемента. По комплексу признаков эта форма интерпретируется как поздняя корнезубая стадия одной из филетических линий, ведущей к современным скальным полевкам Alticola. Наиболее близким сходством она обладает с плоскочерепными полевками $A$. strelzowi. Эта форма описывается как новый род и новый вид, Altaiomys ustkanicus gen. \& sp. nov.

КЛЮЧЕВЫЕ СЛОВА: Arvicolinae, Alticola, эволюция, ранний плейстоцен, Алтай, Россия.

\section{Introduction}

The Ust'-Kan cave is situated in the Belyi Kamen' mountain massive built with specifically light-colored Silurian (Llandovery-Wenlock) limestones. The cave is located on the right bank of the Charysh River in 3.5 $\mathrm{km} \mathrm{E}$ from the district center, the Ust'-Kan settlement, $50^{\circ} 54^{\prime} 40^{\prime \prime} \mathrm{N}, 84^{\circ} 48^{\prime} 50^{\prime \prime} \mathrm{E}$. The cave has a southwestern orientation. The entrance is at $45 \mathrm{~m}$ above the river level and at $1037 \mathrm{~m}$ above sea level. The cave was discovered and thoroughly studied by Rudenko in the middle of the last century (Rudenko, 1960, 1961). In late 1990s new excavations of the site were started by the Institute of archaeology and ethnography of the Siberian Division of the Russian Academy of Sciences. The Pleistocene sequence of the Ust'-Kan Cave have been divided into 12 levels, some of them with minor morphological subdivisions. Most levels produced ar- chaeological materials of the Mousterian (Derevyanko et al., 2001; Agadjanian et al., 2003). Small mammal remains are common in every level. They are represented by isolated teeth, fragmentary long bones, and vertebrae. The overall faunal composition of beds 1 through 8 indicates Late Pleistocene age. The lower levels (12 through 9), which are distinctly red-colored, yielded a mixed assemblage combining Late Pleistocene forms and species typical for earlier intervals of Pleistocene (Tab. 1). Three associations of late Middle Pleistocene, and two Early Pleistocene age are defined analytically.

Early and Middle Pleistocene faunas were previously unknown in Central Altai. This is why the discovery of archaic voles in the lower levels of the Ust'-Kan Cave has a great scientific value. The most archaic association of the locality is dated to the earliest stage of Early Pleistocene, early Biharian by the presence of the primitive lagurine Prolagurus ternopolitanus Topachevsky, 1973. 
Table 1. Associations of Early and Middle Pleistocene voles of the Ust-Kan Cave.

\begin{tabular}{|l|l|c|}
\hline Age & Species & Beds \\
\hline \multirow{5}{*}{$\begin{array}{l}\text { Late } \\
\text { Pleistocene }\end{array}$} & $\begin{array}{l}\text { Lagurus lagurus, Microtus gregalis, } \\
\text { M. arvalis, M. agrestis, M. hyper- } \\
\text { boreus, M. oeconomus, Arvicola } \\
\text { terrestris, Lemmini, Alticola macrotis, } \\
\text { A. strelzowi, Clethrionomys rutilus, C. } \\
\text { rufocanus }\end{array}$ & \multirow{2}{*}{$7-1$} \\
\hline \multirow{5}{*}{$\begin{array}{l}\text { Middle } \\
\text { Pleistocene }\end{array}$} & $\begin{array}{l}\text { Lagurus transiens } \\
\text { Arvicola mosbachensis } \\
\text { Eicrotus gregaloides }\end{array}$ & \\
\hline Pleistocene & $\begin{array}{l}\text { Allophaiomys pliocaenicus } \\
\text { Microtus hintoni } \\
\text { Prolagurus pannonicus } \\
\text { Mimomys intermedius }\end{array}$ & \multirow{2}{*}{$12-8$} \\
\cline { 2 - 3 } & $\begin{array}{l}\text { Allophaiomys deucalion } \\
\text { Prolagurus ternopolitanus } \\
\text { Mimomys spp. } \\
\text { Altaiomys ustkanicus gen. \& sp. nov. }\end{array}$ & \\
\hline
\end{tabular}

\section{Material and methods}

All specimens described below are preserved in the collection No. 4837 in the Paleontological Institute of the Russian Academy of Sciences (PIN). The material consists of four isolated molars: right $\mathrm{m} 1$ (PIN 4837/1), left m1 (PIN 4837/2), right M1 (PIN 4837/3), left M2 (PIN 4837/4). Nomenclature of arvicoline occlusal surface mainly follows the system of Gromov \& Polyakov
(1977) and Meulen (1973). Terminology of dentine tracts is after Rabeder (1981), measurements are after Tesakov (2004), and enamel quotient measurements (SDQ) are after Heinrich (1990). Lower case m denotes lower molars, upper case M stand for uppers. All measurements are in $\mathrm{mm}$.

\section{Systematic paleontology}

Family Cricetidae Fischer, 1817

Subfamily Arvicolinae Gray, 1821

Tribe Clethrionomyini Hooper \& Hart, 1962

Genus Altaiomys Serdyuk \& Tesakov, gen. nov.

Altaiomys ustkanicus Serdyuk \& Tesakov, sp. nov. Fig. 1.

Etymology. The genus name is after the Altai Mountains, the species name is after the Ust'-Kan settlement.

Holotype. PIN 4837/1, left lower molar (2.5 x 1.05).

Paratype. PIN 4837/2, right lower molar (2.5 x 1.02).

Referred material. In addition to type specimens, two upper molars M1 (PIN 4837/3) and M2 (PIN 4837/4) are referred to the new form tentatively.

Type locality. Central Altai, Ust-Kan District, right bank of Charysh River, Ust'-Kan Cave; Early Pleistocene.

Diagnosis. Clethrionomyine vole with molar roots, cement, undifferentiated or slightly negative enamel. $\mathrm{HH}$-index above 5 . Anterosinuid in $\mathrm{m} 1$ not split.

Description. (Fig. 1). The vole of medium size (Tabs. 2 and 3). Molar roots are present. Cement is sparse in reentrants in ontogenetically younger molars and tends to be heavier with wear. The enamel is rela-

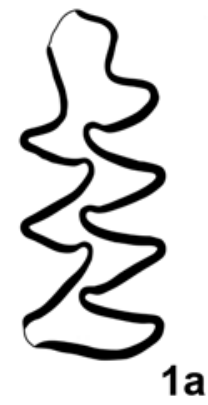

$1 a$

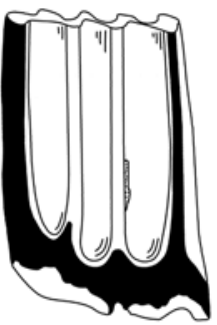

1b

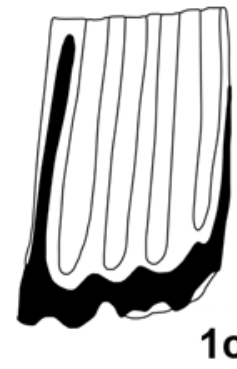

1c

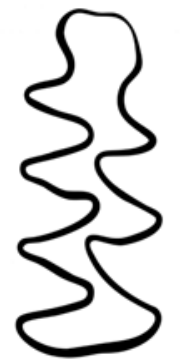

2a

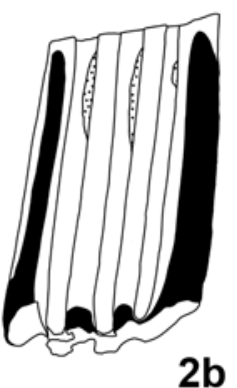

2b

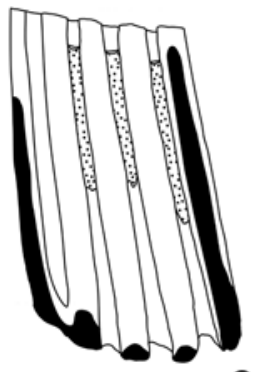

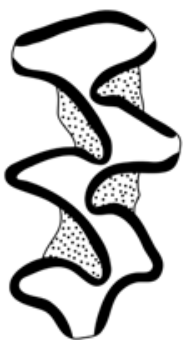

$3 a$

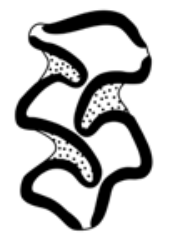

$4 a$

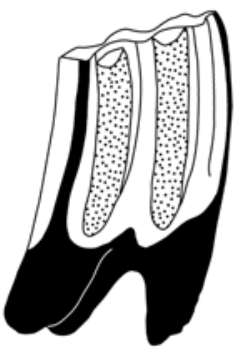

3b

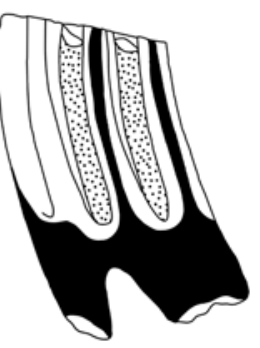

3c

Figure 1. Molars of Altaiomys ustkanicus gen. \& sp. nov. (1 and 2) and molars provisionally referred to this taxon (3 and 4$)$ in occlusal (a), labial (b), and lingual (c) views.

1 - PIN 4837/1, left m1;2 - PIN 4837/2, right m1;3 - PIN 4837/3, right M1; 4 - PIN 4837/4, left M2. Scale bars are $1 \mathrm{~mm}$; larger scale stands for the occlusal view, smaller one, for the labial and lingual views. 
Table. 2. Measurements of lower molars of Altaiomys ustkanicus gen. \& sp. nov.

\begin{tabular}{|l|c|c|c|c|c|c|c|c|c|c|}
\hline \multirow{2}{*}{ Specimen } & \multicolumn{10}{|c|}{ Measurements } \\
\cline { 2 - 12 } & L & W & A & H & R & Asd & Hsd & Hsld & HH-index & Lbas \\
\hline PIN $4837 / 1, \mathrm{~m} 1$ & 2.5 & 1.05 & 1.1 & 3.3 & 0.2 & $>3.5$ & $>3.35$ & 3.55 & $>4.9$ & 3.05 \\
\hline PIN $4837 / 2, \mathrm{~m} 1$ & 2.5 & 1.02 & 0.95 & 4.25 & - & 4.2 & 4.15 & 4.3 & 5.98 & 2.9 \\
\hline
\end{tabular}

Table 3. Measurements of upper molars of Altaiomys ustkanicus gen. \& sp. nov.

\begin{tabular}{|l|c|c|c|c|c|c|c|c|}
\hline \multirow{2}{*}{ Specimen } & \multicolumn{7}{|c|}{ Measurements } \\
\cline { 2 - 9 } & L & W & H & R & As & Prs & PA-index & Lbas \\
\hline PIN 4837/3, M1 & 2.35 & 1.05 & 2.8 & 1.1 & $>2.7$ & $>2.9$ & $>3.96$ & 2.15 \\
\hline PIN 4837/4, M2 & 1.57 & 1.02 & 2.42 & 0.75 & $>2.45$ & $>2.45$ & $>3.45$ & 1.6 \\
\hline
\end{tabular}

tively undifferentiated along the perimeter of occlusal surface or weakly negatively differentiated (mimomyan type) and slightly thins out in the tips of reentrant angles. Hypsodonty stage is advanced with interruption of dentine tracts by wear taking place nearly simultaneously with the reentrant closing at the molar base. Anterosinuid (Fig. 2b) in $\mathrm{m} 1$ has a rounded unicuspid tip.

Lower $\mathrm{m} 1$ is composed of posterior loop, three basic triangles and anteroconid complex with broadly confluent T4 and T5 and rounded cap, though the communication between enamel fields of T4 and T5 is the shortest. Cement is present in both specimens, though it is poorly preserved in the holotype. No enamel islet or Mimomys-ridge is present.

Upper M1. The molar is composed of the anterior loop and four alternating triangles. Two roots are present with the anterior one still bearing signs of the fusion with the protocone root. Triangular fields have regular shape; enamel fields are almost isolated from each other by strongly posteriorly curving (retrovergent) reentrants. Posterior lingual reentrant (LRA3) is deep.

Upper M2 is built of the anterior loop and three alternating triangles. Two rounded roots are present. Reentrant angles are strongly curving. LRA3 is deep.

Measurements. For dental measurements see Tabs. 2 and 3. Enamel measurements indicate a slightly negative or Mimomys-type differentiation with SDQ values of $\mathrm{m} 1$ specimens being estimated at 102.97 (PIN 4837/ 1) and 107.2 (PIN 4837/1). Values for upper molars are 106.1 (PIN 4837/3) and 107.6 (PIN 4837/4).

Comparison. The new genus differs from Clethrionomys Tilesius, 1850 in more pointed enamel prisms, more undifferentiated enamel, generally more isolated dentine fields and more curving reentrant angles. It also differs from most species of Clethrionomys in higher hypsodonty and larger size.

From nearly equally hypsodont Clethrionomys mirus Savinov \& Tutkova, 1987 from Late Pliocene-Early Pleistocene of southern Kazakhstan (Kozhamkulova et al., 1987; Tjutkova \& Kaipova, 1996) it differs in more symmetrical anteroconid and more alternating T4 and T5.
From Alticola Blanford, 1881 it differs in the presence of molar roots and in less differentiated enamel band.

In comparison to Late Pliocene "Villania" fanchangensis (Zhang et al., 2006), the clethrionomyine vole from south-eastern China, the Altai vole shows more advanced levels of most evolving dental characters: higher hypsodonty and more isolated triangles.

From late Pliocene Transbaikalian voles of "Villanyia" klochnevi (Erbajeva, 1998, 2005), a probable rhizodont alticoline vole, the new Altai vole differs in the presence of cement and more differentiated anteroconid part of $\mathrm{m} 1$.

From unrelated but superficially similar genera of mimomyian voles the new form differs in following characters:

From Mimomys Major, 1902, in much less prefect negative enamel differentiation and less abundant cement.

From Central Asian voles of Borsodia chinensis (Kormos, 1934) group (Zheng \& Li, 1986; Erbajeva, 2005), as well as from other hypsodont rhizodond lagurines, in the presence of cement and undifferentiated rather than positively differentiated enamel.

Remarks. The vole from the Ust'-Kan Cave has a specific combination of characters unknown in any recent forms. But the general outline of occlusal surface indicates affinities with the tribe Clethrionomyini and resembles dental features of some recent Alticola. As the molars with roots are primitive character in arvicolines, we tentatively interpret the new form as a late rhizodont stage of one of phyletic lineages of modern high mountain voles of the genus Alticola. We should probably rule out any affinities with voles of the subgenus Aschizomys Miller, 1899, because the latter preserved some "Clethrionomys"-like dental characters missing in Altaiomys gen. nov.

The undifferentiated enamel, small amount of cement and well separated dentine fields in occlusal surface make the new form primitive regarding any recent species of Alticola s. str. One of the morphological matches is the flat-sculled vole, Alticola strelzowi Kastschenko, 1899. The labial anteroconid triangle of 
$\mathrm{m} 1$ has a tendency to separation from anteroconid cap and T5, making the teeth comparable to the simplest morphotype of A. strelzowi (Serdyuk, 2000). Two upper teeth also have Alticola-like appearance, but at this stage of the study we assign them to the new form only provisionally.

\section{Discussion}

The fossil record of Alticola is extremely scarce and reliably starts in late Early Pleistocene of peri-Baikalian Russia (Alexeeva, 1998) and Middle Pleistocene of China (Young, 1934; Pei, 1936). In caves of Russian Altai, the fossil record of $A$. strelzowi and A. macrotis Radde, 1861 starts at least from the beginning of Late Pleistocene (Agadjanian \& Serdyuk, 2005). Thus we assign Altaiomys ustkanicus gen. \& sp. nov. to the earliest Early Pleistocene assemblage present in the Ust'-Kan Cave lower beds material (Tab.1).

In the dental systematics of arvicolines, the presence or absence of molar roots has long been regarded as a genus level criterion (Hinton, 1926; Gromov, 1972; and many others). A strong argument in favor of this point is that in the extant fauna no widely accepted genus combines both rooted and rootless forms (Zazhigin, 1980). Although biological meaning of this criterion is controversial, the disappearance of molar roots in evolution of a certain lineage of voles usually means an origin of a new genus for most researchers (for instance, the well known case of Mimomys/Arvicola transition). The apparent discovery of a rhizodont alticoline vole in Central Altai provides a long needed clue for the origin and evolution of Asian high mountain voles. If our conclusion is true, no later than in Early Pleistocene the Altai region was populated by a very hypsodont vole, which most probably elaborated completely rootless dentition during this time interval. The morphological evidence permits to consider the newly described form as an ancestor of some recent species of the nominative subgenus of Alticola. One of the probable matches is the flat-sculled vole, A. strelzowi. However, the new Altai vole is too plesiomorphic to draw a definite conclusion at this stage of its knowledge. It may also be ancestral to more than one recent species of Alticola (Alticola).

ACKNOWLEDGEMENTS. We thank our colleagues, A.K. Agadjanian (PIN RAS), V.S. Zazhigin (GIN RAS), Jin Changzhu (IVPP AC), Zhang Yinggi (OCU), for helpful discussions. Sincere thanks also go to A.V. Postnov for granting: the material from the Ust'-Kan Cave. The work was supported by the projects nos. 05-04-48493, 06-0449294, 06-05-64049, SS-6228.2006.4 of the Russian Foundation for Basic Research.

\section{References}

Agadjanian A.K. \& Serdyuk N.V. 2005. History of mammalian communities and paleogeography of Altai Mountains in the Paleolithic// Paleontological Journal. Vol.39.
Supplementary No.6. P.645-820.

Agadjanian A.K., Serdyuk N.V. \& Postnov A.V. 2003. [Multidisciplinary studies of artifact bearing deposits of the Ust'-Kan Cave] // Vestnik Tomskogo Gosudarstvennogo Universiteta, Seriya Geologicheskaya. No.3(II), Supplement. P.26-28 [in Russian].

Alexeeva N.V. 1998. Paleoecology of Transbaikal Allophaiomys faunas // Paludicola. Vol.2. No.1. P.16-19.

Gromov I.M. 1972. Systematic groups above species level in the vole subfamily (Microtinae) and their possible affinities // Trudy Zoologicheskogo Museya Moskovskogo Gosudarstvennogo Universiteta. No.13. P.8-33 [in Russian]. Gromov I.M. \& Polyakov I.Ya. 1977. [Fauna of the USSR: Mammals: Voles] // Leningrad: Nauka. 504 p. [in Russian].

Derevyanko A.P., Agadjanian A.K., Kulik N.A. et al. 2001. [Main results of investigation of multi-layered site Ust'Kan Cave in 1998-2001] // Problemy arkheologii, etnografii i antropologii Sibiri i sopredel'nykh territorii. T.7. P.109-114 [in Russian].

Erbajeva M.A. 1998. Late Pliocene Itantsinian faunas in Western Transbaikalia. // Mededelingen Nederlands Instituut voor Toegepaste Geowetenschappen TNO. No.60. P.419-430.

Erbajeva M.A. 2005. [Fossil voles of Transbaikalia and Northern China] // Abramson N.I. \& Averianov A.O. (eds.). [Systematics, Paleontology, and Phylogeny of Rodents]. Trudy Zoologicheskogo Instituta RAS. T.306. P.55-71 [in Russian].

Heinrich W.D. 1990. Some aspects of evolution and biostratigraphy of Arvicola (Mammalia, Rodentia) in the Central European Pleistocene // Fejfar O. \& Heinrich W.D. (eds.). International Symposium of Evolution Phylogeny and Biostratigraphy of Arvicolidae. Praha: Pfeil. P.165-182.

Hinton M.A.C. 1926. Monograph of the voles and lemmings (Microtinae) living and extinct. Vol.1. London: British Museum (Natural History). 488 p.

Kozhamkulova B.S., Savinov P.F., Tjutkova L.A. \& Pak T.K. 1987. [Pliocene mammals of Aktagay] // Materialy po istorii fauny i flory Kazakhstana. T.9. P.82-121 [in Russian].

Meulen, A., van der. 1973. Middle Pleistocene smaller mammals from the Monte Peglia (Orvieto, Italy) with special reference to the phylogeny of Microtus (Arvicolidae, Rodentia) // Quaternaria. Vol.17. P.1-144.

Pei W.C. 1936. On the mammalian remains from locality 3 Choukoutien // Paleontologica Sinica, Series C. Vol.7. No.5. P.70-75.

Rabeder G. 1981. Die Arvicoliden (Rodentia, Mammalia) aus dem Pliozän und dem älterem Pleistozän von Niederösterreich // Beiträge zür Paläontologie von Österreich. Bd.8. S.1-343.

Rudenko S.I. 1960. [Ust'-Kan Cave Paleolithic site] // Materialy i issledovaniya po arkheologii SSSR. No.79. P.104125 [in Russian].

Rudenko S.I. 1961. The Ust'-Kanskaia Paleolithic cave site, Siberia // American Antiquity. Vol.27. No.2. P.203-215.

Serdyuk N.V. 2000. [Morphological differences of first lower molar of Alticola strelzowi and Alticola macrotis] // Agadjanian A.K. \& Orlov V.N. (eds.). [Systematics and 
Phylogeny of Rodents and Lagomorphs]. Moskva: Teriologicheskoe Obshchestvo. P.153-156 [in Russian].

Tesakov A.S. 2004. [Biostratigraphy of Middle PlioceneEopleistocene of Eastern Europe (Based on Small Mammals)]. Moskva: Nauka. 247 p. [in Russian].

Tjutkova L.A. \& Kaipova G.O. 1996. Late Pliocene and Eopleistocene micromammal faunas of southeastern Kazakhstan // Acta Zoologica Cracoviensia. Vol.39. No.1. P.549-557.

Young C.C. 1934. On the Insectivora, Chiroptera, Rodentia and Primates other than Sinanthropus from locality 1 of the Choukoutien // Paleontologica Sinica, Series C. Vol.8. No.3. P.1-160
Zazhigin V.S. 1980. [Late Pliocene and Anthropogene Rodents of the South of Western Siberia]. Moskva: Nauka. 155 p. [in Russian].

Zhang Y.Q., Kawamura Y. \& Jin C.Z. 2006. A new species of the extinct vole Villanyia from the Early Pleistocene of Central China, with comments on the relationship to the Transbaikalian species // Stratigraphy, Paleontology and Paleoenvironment of Pliocene-Pleistocene of Transbaikalia and Interregional Correlations. Abstracts of the International Conference. Ulan-Ude: Buryatian Scientific Center of the Siberian Division of RAS. P.99.

Zheng S. \& Li C. 1986. A review of Mimomys in China // Vertebrata PalAsiatica. Vol.24. No.2. P.81-109. 